\title{
Pleonazm jako reduplikacja semantyczna we współczesnym języku niemieckim
}

Pleonasms as a Semantic Reduplication in Contemporary German

\author{
Pawel BĄK \\ Uniwersytet Rzeszowski/ University of Rzeszów \\ E-mail: wort.pb@wp.pl
}

\begin{abstract}
The present paper discusses diverse aspects of pleonasms in different types of German discourses. Pleonasm, similarly to tautology, is a strongly criticised phenomenon, not only by regular language users, but also by linguists, especially lexicographers. It does not change the fact, that it is widely used in different discourse types, especially in spoken and technical ones. It appears also on different levels of the language structure. It occurs that it is a mechanism of the language use and it should not be treated a priori as a mistake, because it is a specific language universal, present in different languages around the world.
\end{abstract}

Keywords: pleonasm, linguistic error, redundancy, tautology, semantic reduplication

\section{Wstęp}

W realizowanych w różnorakich dyskursach wypowiedzeniach zaobserwować można przejawy redundancji, powielanie oraz powtarzanie treści, nadwyżki dotyczące kategorii leksykalnych, semantycznych oraz powtórzenia w zakresie realizacji kategorii gramatycznych. Wspomniane ostatnie zagadnienia dotyczą wielu języków, w których formy reduplikacji semantycznej uzależnione są od specyfiki morfologii, np. wyspecjalizowania afiksów czy też wielofunkcyjności formantów (por. np. A. Dauses 2000: 37). Przy rozpatrywaniu tych aspektów uwzględnić należy miejsce, jakie dany język zajmuje w morfosyntaktycznej klasyfikacji strukturalnej, tj. typologii języków, mając na uwadze zwłaszcza jego mniej lub bardziej zaawansowaną analityczność bądź syntetyczność, a w drugim przypadku - przewagę fleksji nad aglutynacją lub relację odwrotną.

W poniższych rozważaniach zwrócę uwagę na zjawisko reduplikacji semantycznej w języku niemieckim, objawiającej się przede wszystkim w postaci pleonazmu lub tautologii. Centralne miejsce w niniejszej refleksji zajmuje pleonazm transkategorialny. Dostrzeżenie tego zjawiska w różnych obszarach i na kilku poziomach struktur gramatycznych języka niemieckiego jest moim zdaniem ważne w rozważaniach dotyczących jego funkcjonowania i dla zrozumienia stopnia wykorzystania struktur morfosyntaktycznych w ramach konkretnych ludzkich idiolektów (por. F. Grucza 2017a: 66; F. Grucza 2017b: 123; 2017c: 153 i nast.; S. Grucza 2013: 87, 
$120)^{1}$. Rozważania te dotyczyć mogą wielu kategorii, m.in. leksykalnych, syntaktycznych, morfologicznych, a w słowotwórstwie - derywacji oraz kompozycji, rozpatrywanych $\mathrm{w}$ paradygmacie semantyki i pragmalingwistyki ${ }^{2}$. Aspekty te omawiam na przykładzie współczesnego języka niemieckiego, który wykazuje się bardziej zawansowaną analitycznością niż język polski, z zachowaniem jednak większej niż np. w języku angielskim tendencji do generowania form syntetycznych (por. W. v. Humboldt 1836/1963: 144 i nast., F. Grucza 2017a: 66 i nast., 2017b: 123 i nast., 2017c: 153 i nast.; L. Hoffmann 1998: 416 i nast.; T. Roelcke 2002: 179 i nast., 2004: 147 i nast. $)^{3}$. W odniesieniu do niego można moim zdaniem mówić o szczególnej potrzebie dostrzeżenia zjawiska reduplikacji semantycznej, mając na uwadze zwłaszcza fakt, iż na temat wszechobecności reduplikacji w języku niemieckim nie powstały dotychczas szersze opracowania monograficzne.

W niniejszych rozważaniach posługuję się terminem „reduplikacja semantyczna” (w skrócie „reduplikacja”) rozumianym jako kategoria nadrzędna w stosunku do pojęć „pleonazm” i „tautologia”. Nie jest on w tym znaczeniu tożsamy z zakresem znaczeniowym terminu ,reduplikacja” opisywanym jako powtórzenie, podwojenie rdzenia lub jego części ${ }^{4}$.

\footnotetext{
${ }^{1}$ Zjawisko redundancji oraz reduplikacji dostrzec można na wielu płaszczyznach, które na przykładzie języka polskiego wyróżniła i omówiła szczegółowo D. Buttler (1971) oraz - w cennym opracowaniu monograficznym „Słowa w lustrze. Pleonazm - semantyka - pragmatyka" - A. Małocha-Krupa (2003). Autorka przytacza bogatą w literaturze polskiej literaturę na ten temat oraz precyzyjnie ujmuje przedmiot swych dociekań.

${ }^{2}$ Uwzględnienie aspektów pragmalingwistycznych w innym kontekście dotyczy zwłaszcza tautologii (por. P. Bąk 2011b, 2011c).

${ }^{3} \mathrm{~W}$ niniejszych rozważaniach, przy podejściu systemowym nie jest możliwe wyczerpujące omówienie funkcjonowania zjawiska powtórzeń we wszystkich zakresach kategorialnych. $\mathrm{W}$ artykule tym skoncentruję się na najważniejszych aspektach dotyczących reduplikacji semantycznej realizowanej za pośrednictwem wybranych struktur niemieckich, proponując ich wstępną typologię. Pewne aspekty, do których nawiązuje niniejsza praca, poruszyłem w artykułach (P. Bąk 2011a, 2011b, 2011c, 2015). Dogłębne zbadanie zjawiska wymaga jednak podejścia wychodzącego poza ramy systemu języka, uwzględniającego m.in. aspekty pragmalingwistyczne, implikaturę konwersacyjną P. Grice'a (1975), model relewancji D. Sperbera i D. Wilson (D. Sperber/ D. Wilson 1986) oraz - przede wszystkim - potraktowania inklinacji użytkownika języka do powtórzeń i realizacji wypowiedzi o charakterze redundantnym jako jego naturalnej potrzeby precyzyjnego wyrażania myśli w oparciu o zinternalizowaną przez niego wiedzę gramatyczno-leksykalną. Na temat wykorzystania mocy generatywnej języków w kontekście lingwistyki historiograficznej szerzej wypowiada się F. Grucza (2017c: 153 i nast.).

${ }^{4}$ Terminem reduplikacja w zupełnie innym rozumieniu operuje np. „Encyklopedia Językoznawstwa Ogólnego”: „Operacja morfologiczna o charakterze słowotwórczym lub fleksyjnym polegająca na podwojeniu rdzenia w całości lub na podwojeniu części rdzenia" (Encyklopedia Językoznawstwa Ogólnego 1999: 483, por. D. Antoniak 2005: 1).
} 


\section{Tautologia i pleonazm w taksonomii. O konieczności systematyzacji pojęć}

W świadomości przeciętnych użytkowników języka, ale i w literaturze przedmiotu reduplikacja semantyczna, tautologia i pleonazm, funkcjonują najczęściej jako synonim redundancji, potoczne metajęzykowe ,masło maślane ${ }^{5 "}$. Co znamienne, sam pleonazm objaśniany jest przez leksykografię językoznawczą w sposób (meta) pleonastyczny: „Pleonazm - wyrażenie zawierające człony ze względów semantycznych zbyteczne, najczęściej redundantne [...]” (,Encyklopedia Językoznawstwa Ogólnego" 1999: 438, wyróżnienie - P. B.). Jeżeli w literaturze przedmiotu ma miejsce rozróżnienie obydwu terminów, wówczas pleonazm pojawia się tu częściej jako naruszenie normy i błąd językowy (por. A. Małocha-Krupa 2003: 8 i nast.). Tautologia objaśniana jest przy tym ponadto jako powtórzenie formy, cecha stylu, niekiedy repetycja czy wręcz aliteracja (por. ibid.: 29 i nast.). W literaturze ${ }^{6}$, zwłaszcza polskojęzycznej (także tej nowszej), tautologia opisywana jest przez przywołanie stosunku współrzędności powtórzonych członów, zespolenia jednostek tożsamych treściowo lub przynajmniej zbliżonych do siebie semantycznie (por. D. Buttler 1971: 249, A. Małocha-Krupa 2003: 34$)^{7}$. Termin pleonazm częściej objaśniany jest jako określenie grup wyrazowych zespolonych stosunkiem determinacji (por. D. Buttler 1971: 251 i nast.). Jedna $z$ nowszych, trafnych definicji uznaje za pleonazm: „dwuczłonow[ą] syntagm[ę] na mocy kodu zwierając[a] reduplikację semantyczną i pozostając[a] w stosunku bezpośredniej determinacji składniowej" (A. Małocha-Krupa 2003: 8). Z tak systematycznym podejściem mamy jednak do czynienia w przypadku konsekwentnego rozgraniczenia pojęć tautologii i pleonazmu, które - inaczej niż u przytoczonych wyżej autorek - w literaturze przedmiotu niestety nie jest regułą ${ }^{8}$. W tym kontekście warto zauważyć, że samo to rozróżnienie nie znajduje bezpośredniego przełożenia na definitywne wyjaśnienie fenomenu akceptowalności, z jaką nierzadko mamy do czynienia w przypadku mechanizmu reduplikacji (i tautologii, i pleonazmu), mimo że a priori mogło by się wydawać, iż jest zupełnie inaczej. Niemniej rozgraniczenie to jest ważnym głosem w merytorycznej dyskusji na temat istoty zjawiska. Porządkuje ono kategoryzację pojęć związanych z reduplikacją i czyni zasadną zaproponowaną poniżej typologię jej form.

\footnotetext{
${ }^{5}$ Zgodnie ze „Słownikiem wyrazów obcych PWN” pleonazm wywodzi się od greckiego pleonasmós (gr.), po łacinie pleonasmos, oznaczając nadmiar. „Tautología” (gr.). Tautologia (gr.) to ,zdanie, powiedzenie powtarzające niepotrzebnie to, co już w wypowiedzi było zawarte” (Słownik wyrazów obcych PWN).

${ }^{6}$ Począwszy od D. Buttler (1971: 249 i nast.). Więcej na ten temat por. A. Małocha-Krupa (2003: 34).

7 Tautologia jest niekiedy ograniczana do przypadków reduplikacji z zachowaniem formy, brzmienia wyrażeń (por. D. Buttler 1971: 249 i nast., A. Małocha-Krupa 2003: 34).

${ }^{8}$ Inaczej kategorie te traktuje np. „Encyklopedia Językoznawstwa Ogólnego” (1999: 594 i nast.), przypisując relację determinacji także tautologii. Także w niemieckojęzycznym dyskursie naukowym, w leksykografii i literaturze językoznawczej rzadko znajdziemy systematyczne podejście do obydwu terminów (por. M. Hoffmann 2008: 1502, 1539).
} 


\section{Powtórzenie jako błąd językowy?}

$\mathrm{Na}$ co dzień często można spotkać się z ocenami, które zjawiskom pleonazmu oraz tautologii wydawane są niejako a priori. ${ }^{9}$ Są one obecne w świadomości przeciętnego człowieka jako synonim potocznego, metajęzykowego określenia „masło maślane”. Przeważające negatywne oceny wydawane są pleonazmom oraz tautologii w niemieckojęzycznej publicystyce, literaturze popularnonaukowej, poradnikach językowych oraz krytycznej leksykografii (por. W. Sanders 1996, W. Schneider 1998, B. Sick 2007, Duden - Richtiges und gutes Deutsch [=DR]). Reduplikacje posiadają tutaj status niedoskonałości językowej. Dotyczy to wielu przykładów reduplikacji (por. np. (1)) potraktowanych w krytyczny sposób przez poradnik o - nomen est omen - niemal tautologicznym tytule „Duden - Richtiges und gutes Deutsch ${ }^{10}$,.

Stwierdzana przewaga ocen negatywnych, często wydawanych reduplikacji niejako z góry, jedocześnie jej znaczna frekwencja w rzeczywistym języku niemieckim, wreszcie odczuwalny brak obszernych opracowań naukowych na ten temat, uzasadniają celowość zainteresowania się tą problematyką, eksploracji współczesnych dyskursów niemieckojęzycznych pod tym kątem i formułowania wniosków w oparciu o możliwie jak najbogatszy materiał językowy. Uważam, że spojrzenie na te zjawiska wymaga neutralnego podejścia do problematyki, tzn. takiego, które nie neguje z góry, unika generalizacji, docieka przyczyn i poszukuje funkcji komunikatywnych zjawisk językowych. Celem niniejszych rozważań nie jest zatem ograniczanie się do domniemanego negatywnego wymiaru pleonazmu, ale nie jest nim także bezkrytyczna obrona wartości komunikacyjnej czy niepoparte przykładami deklarowanie funkcjonalności pragmatycznej pleonazmu jako jednej z możliwych form reduplikacji. W niniejszej refleksji ograniczę się do opisu językowego kształtu, jaki niemieckojęzyczne reduplikacje, w tym przede wszystkim pleonazmy, przybierają w dyskursach, a także ich głównych cech. W tych oraz kolejnych rozważaniach pragnę zwrócić uwagę na dostrzeganą dziś, choć głównie w literaturze popularnonaukowej ${ }^{11}$, wszechobecność reduplikacji semantycznej $\mathrm{w}$ języku niemieckim, określenie przyczyn tworzenia $\mathrm{i}$ znacznej frekwencji pleonazmów, by móc wreszcie odpowiedzieć na pytanie o ich komunikacyjne funkcje $\mathrm{e}^{12}$.

\footnotetext{
${ }^{9}$ Pomija się przy tym różnorakie komunikacyjne funkcje tautologii oraz pewne zapotrzebowania na pleonastyczne środki wyrazu.

${ }^{10}$ Dalej podaję jako [DR].

11 Jak już wspomniałem, skąpa na temat obecności zjawiska w języku niemieckim refleksja ogranicza się przede wszystkim do piśmiennictwa leksykograficznego, popularnonaukowego i poradników językowych. Wyjątki stanowią nieliczne prace np. P. Staniewskiego (2010) i P. Bąka (2011a, 2011b, 2011c, 2015). Pierwsze spostrzeżenia dotyczące obecności pleonazmów i tautologii we współczesnym języku niemieckim przedstawiłem w Łodzi w dniu 24. czerwca 2010 roku na międzynarodowej konferencji „Felder der Sprache - Felder der Forschung. Lodzer Germanistikbeiträge. (por. P. Bąk 2011c).

12 Pozbawione uprzedzeń spojrzenie na zjawisko pleonazmu, który niewątpliwie ma swój udział w funkcjonowaniu i rozwoju języka, stwierdzić należy w cytowanej powyżej monografii Małochy-Krupy z 2003 roku.
} 


\section{Egzemplifikacja}

Przyjrzyjmy się charakterystycznym dla języka niemieckiego formom pleonazmów. Przytoczone poniżej przykłady ilustrują językowy kształt, jaki pleonazm najczęściej przybiera we współczesnych dyskursach niemieckojęzycznych. Wobec stwierdzonej kreatywności twórców pleonazmów możliwe jest istnienie wielu innych, w tym pojawienie się nowych reduplikacji, które wpiszą się w poniższe grupy ${ }^{13}$. Liczne spośród przykładów odnotowane są przez leksykografię w neutralny sposób jako istniejące jednostki leksykalne (13) (por. [DUW]). Frekwencja tych wyrażeń oraz swoista kreatywność użytkowników języka niemieckiego przemawiają za zabraniem głosu w sprawie akceptowalności dla tego zjawiska.

\section{Relacja przydawka - wyraz określany}

(1) alter Greis [DR] (sędziwy starzec) $)^{14}$;

anfängliche Startschwierigkeiten [BS1] (początkowe trudności startowe) (por. P. Bąk 2015);

eckige Kante [forum] (kanciasty kant);

im augenblicklichen Moment [BS1] (w chwilowym momencie);

kleiner Zwerg [DR] (mały karzeł);

runde Kugel [BS2], [NS] (okrągła kula);

runder Kreis [BS2] (owalny okrąg);

tote Leiche [BS1] (martwe zwłoki);

weibliche Kandidatin [BS2] (kandydatka płci żeńskiej);

weißer Schimmel [DR] (funkcjonalny odpowiednik polskojęzycznego potocznego metapleonazmu masto maślane, por. (2) doppelt gemoppelt).

Relacja werboadwerbialna: okolicznik - orzeczenie ${ }^{15}$

(2) nutzlos vergeuden [DR] (bezczynnie trwonić/marnować (czas)); weiter fortfahren [DR] (kontynuować dalej);

13 Nie chodzi w tym kontekście o wyczerpujące i definitywne wyodrębnienie klas pleonazmów. Przytoczone przykłady wchodzą w skład obszernego, od 2008 roku rozbudowywanego korpusu. Wyabstrahowane na podstawie przykładów grupy pozwalają stwierdzić pewne tendencje w rozwoju leksyki współczesnego języka niemieckiego.

${ }^{14}$ Niektóre spośród powyższych przykładów przytoczyłem obok innych pleonazmów w artykule „Sind Wiederholungen immer redundant? Zu Formen und Funktionen von Pleonasmen im Bereich der Wortbildung” (P. Bąk 2011: 33 i nast.). W dalszej części artykułu przytaczam też nowe lub niedawno odnalezione reduplikacje semantyczne. Sporo przykładów odnotowanych zostało w korpusie Bastiana Sicka (w pracy oznaczone są one symbolami [BS1] i [BS2]). Podawane tu odpowiedniki to polskojęzyczne ,ekwiwalenty” o charakterze interlinearnym. Pełnią one funkcję pomocniczą, służą przedstawieniu formy i mechanizmu reduplikacji w języku niemieckim, jednak nie zawsze są w stanie w pełni oddać funkcjonalnego charakteru każdej reduplikacji w języku niemieckim, np. jednocześnie treści i formy. Nie sposób ponadto oddać przy pomocy ekwiwalentów wszystkich aspektów dotyczących relacji semantycznych między powtarzanymi członami.

${ }^{15}$ Jako dominująca wśród przykładów zachodzi relacja między orzeczeniem a okolicznikiem skutku lub sposobu. Wiele innych przykładów pozwalających przypisać się do tej grupy przytaczam w artykule „Pleonasmus der deutschen Gegenwartssprache” (por. P. Bąk 2015). 
doppelt gemoppelt [BS1] (funkcjonalny odpowiednik polskojęzycznego potocznego metapleonazmu masto maślane, por. (1) weißer Schimmel).

\section{Reduplikacje transkategorialne}

Wspomniane powyżej oraz liczne inne reduplikacje (por. P. Bąk 2011c i 2015) potwierdzają możliwość realizacji powtórzeń za pośrednictwem różnorakich kategorii, nie tylko leksykalnych, ale i gramatycznych, w tym np. różnych form morfologicznych (części mowy) lub syntaktycznych (niejednakowych części zdania). W języku niemieckim realizowane są one szczególnie w zakresie modalności przy użyciu różnorodnych form morfosyntaktycznych. Pozwolę sobie nie komentować w tym miejscu wszystkich pleonazmów z osobna, przytaczając niekiedy wręcz spektakularne, lecz przede wszystkim reprezentatywne przykłady. ${ }^{16}$

(3) Er pflegte gewöhnlich zu ... + czasownik [BS2], [DR] (przeważnie zwykł + coś robić); Es scheint wahrscheinlich ... [BS1], [BS2], [DR] (wydaje się być prawdopodobnym...);

Es kann möglich sein, dass... [BS2], [DR] (jest możliwe, że być może...);

Sie soll angeblich in ... gesehen worden sein. [DR] (rzekomo miała być widziana w...).

W kontekście pytań o akceptowalność reduplikacji, w tym zarówno pleonazmu (4a), jak i tautologii (4b), (4c), (4d), należy zaznaczyć, że powtórzenia tego typu często zwracają na siebie uwagę użytkowników języka i nierzadko trudno jest je uznać za zamierzone zabiegi stylistyczne. Inne natomiast stanowią środek wyrazu umożliwiający wyeksplikowanie istotnych aspektów, często dotyczących usankcjonowania działań ludzi w określonych realiach przeróżnych dziedzin specjalistycznych czy w pewnych uwarunkowaniach prawnych:

(4a) Sie sind nicht berechtigt, unrechtmäßige Kopien anzufertigen. [eB] (Nie jesteście Państwo upoważnieni do bezprawnego sporządzania kopii);

(4b) Die erforderlichen Korrekturen mussten vorgenommen werden. [eB] (musiały zostać dokonane niezbędne korekty);

(4c) einander diametral gegenübergestellt [architekt], [hb] (diametralnie wzajemnie przeciwstawne);

(4d) angeblich und vermeintlich [psycholog: 475] (rzekomo i domniemanie).

Niektóre powtórzenia w zakresie leksykalnym oraz w obrębie kategorii morfosyntaktycznych mają szczególny charakter. Chodzi tu o częste przypadki pozornych błędów językowych. $Z$ pewnością nie są nimi, choć nawet w literaturze popularnonaukowej i poradnikach językowych zostały potraktowane jako takie (neu anfangen, neu immatrikulieren), podobnie jak cała rzesza pleonazmów (por. szczególnie (13)): ${ }^{17}$

(5) neu renovieren [BS], [DR] (poddać renowacji na nowo);

\footnotetext{
${ }^{16}$ Jak odnotowuje literatura niemiecka, głównie leksykografia [DR] i prace popularnonaukowe (zwłaszcza Sick 2007), zjawisko powtórzenia obiektywnej bądź subiektywnej modalności czasownika za pośrednictwem innych części mowy obserwowane jest stosunkowo często także wśród rodzimych użytkowników języka niemieckiego. Wszystkie te przypadki redakcja „Dudena” traktuje jako prototypowe błędy pleonastyczne (por. [DR: 669] oraz Sick 2007: 32).

${ }^{17}$ Więcej informacji na ten temat można znaleźć w leksykonie [DR].
} 
neu anfangen [welt] (zaczynać na nowo); nochmals überprüfen ${ }^{18}$ [DR] (sprawdzać na nowo); neu immatrikulieren [taz7.7.09] (poddać immatrykulacji na nowo/ponownie); noch einmal wiederholen [BS1] (powtórzyć jeszcze raz).

\section{Konstrukcje słowotwórcze}

Ważne miejsce w opisie omawianego zjawiska zajmują niemieckie reduplikacje słowotwórcze. Są to przede wszystkim derywaty, złożenia determinatywne (,Determinativkomposita"), ponadto skrótowce i liczne wyrażenia pochodzenia obcego ${ }^{19}$.

\section{Derywacja}

Przyjrzyjmy się najpierw przypadkom derywacji eksplicytnej (eksplikatywnej). Derywację taką rozumiemy za W. Fleischerem $(1982)^{20}$ jako konstrukcję powstałą W oparciu o morfem rdzenny przez sufiksację lub prefiksację (por. H. Bußmann 2002). W kontekście dotyczącym niemieckojęzycznych pleonazmów na uwagę zasługują konstrukcje werbalne, zwłaszcza czasowniki złożone rozdzielnie. W ich przypadku często zachodzi podejrzenie o redundantny charakter występujących tu przedrostków:

(6) sich an etwas zurückerinnern [DUW], [BS1] (przypominać sobie coś, co było; wracać myślami do czegoś, co było, wstecz);

zusammenaddieren [BS2], [DR] (zsumować razem).

Prefiksy w wielu innych czasownikach, często odnotowanych w słownikach niemieckich, są członami na pozór redundantnymi:

(7) festbinden [DUW] (związać (mocno)) (por. P. Bąk 2011c);

loslassen [DUW] ((wy)puścić, upuścić);

runterdrücken [DUW] (wcisnąć);

zuschlagen [DUW] (domknąć (o drzwiach)).

W odniesieniu do funkcji prefiksu można mówić o dezambiguacji, doprecyzowaniu $^{21}$ czy wzmocnieniu semantyki (szczególnie wyraźne jest to w przypadku leksemu zuschlagen $)^{22}$. W wyrażeniach takich (por. (7)) formanty pełnią rolę modyfikującą znaczenie, służą ujednoznacznieniu bądź zaakcentowaniu semantyki polisemu (los+lassen). Ich frekwencja w dyskursach świadczy o tym, że przez użytkowników języka są akceptowane, mimo że wydobywają istotne, centralne cechy znaczeń.

\footnotetext{
${ }^{18}$ Sam derywat überprüfen traktowany jest w literaturze jako tautologiczny z uwagi na iteratywność formy wyjściowej prüfen (łac. iterare) (wyrażenie wielokrotności czynności). Por. [DR].

${ }^{19} \mathrm{~W}$ pracach z zakresu słowotwórstwa niemieckiego pleonazmom nie poświęcono do tej pory z osobna dostatecznie wiele - by nie powiedzieć - w ogóle uwagi. Por. przypis 33.

${ }^{20} \mathrm{Z}$ oczywistych względów nie można w tym kontekście rozpatrywać derywacji implicytnej, zwanej w literaturze obrazowo derywacją zerową, wewnętrzną lub wsteczną (,implizite Derivation"). Por. W. Fleischer/ I. Barz (1995).

${ }^{21}$ Czasownik lassen jest wyrażeniem polisemicznym.

${ }^{22} \mathrm{~W}$ wymienionych tu przypadkach chodzi o prefiksy wtórne. Na temat pojęcia ,prefiksu wtórnego", tj. przedrostka czasowników rozdzielnie złożonych por. J. Czochralski 1990: 142.
} 
W większości czasowników prefiksy w wymierny sposób modyfikują ich semantykę. W przytoczonych poniżej przypadkach (8) wchodzą jednak w połączenia z leksemami treściowo wyrazistymi, jednoznacznymi. Nie są to ani wyrażenia polisemiczne, ani homonimy, które w danym kontekście wymagałyby dezambiguacji. $\mathrm{W}$ przypadku formantów $a b$-, runter-, über- w poniższych przykładach mogą nasuwać się pewne wątpliwości dotyczące faktycznego „udziału” prefiksów w konstytuowaniu semantyki leksemów i pojawić podejrzenie o redundantny charakter członów słowotwórczych:

(8) absinken [DUW] (spadać, opadać (np. o temperaturze));

runterfallen [DUW] (spadać „W dół”);

überprüfen [DUW] (sprawdzać (dokładnie) $)^{23}$.

Szczególny charakter wykazują czasowniki hinaufsteigen i ansteigen. ${ }^{24}$ Obecność przedrostków hinauf- oraz an- jest w nich pozornie redundantna. W przypadku form wyjściowych, tzn. steigen oraz drücken, niejako na zasadzie oksymoronu istnieje możliwość derywacji absteigen, heruntersteigen, która skutkuje ukonstytuowaniem się znaczenia przeciwnego do treści leksemu wyjściowego steigen.

(9) hinaufsteigen [DUW] (piąć się, wspinać „do góry“);

ansteigen [DUW] (wznosić się, wzrastać);

runterdrücken [DUW] (docisnąć).

Formacje złożeniowo-sufiksalne

Kolejne przykłady reduplikacji to formacje złożeniowo-sufiksalne, konstrukcje opartych na członach, które same są konstrukcjami słowotwórczymi - derywatami. Człony reduplikacji słowotwórczej pozostają jednak względem siebie w relacji współrzędności. Rozpatruję je zatem - w myśl przyjętych za A. Małochą-Krupą (2003) definicji - za konstrukcje tautologiczne. Warto przytoczyć je w tym kontekście z uwagi na fakt, iż obok licznych pleonazmów są one - w przeciwieństwie do omówionych w innym kontekście tautologicznych from bliźniaczych (P. Bąk 2015: 11 i nast.) - konstrukcjami słowotwórczymi:

(10) tagtäglich [DRecht] (dzień w dzień);

wortwörtlich [DRecht] (słowo w słowo) (por. W. Fleischer 1982: 250, P. Bąk 2015: 16).

Derywat wörtlich i - szczególnie - täglich wyrażają cechy o charakterze absolutnym $^{25}$. W kompozycji tej obserwujemy powtórzenie morfemu leksykalnego -rdzenia.

${ }^{23}$ Por. przypis 18.

${ }^{24}$ Czasownik steigen wyraża wprawdzie ruch do góry, wznoszenie się (także w znaczeniu abstrakcyjnym), może jednak posiadać w połączeniu z innymi przedrostkami (herunter- oraz $a b-)$ znaczenie przeciwne.

${ }^{25}$ Przypadki superlatywu absolutnego nie mają charakteru jakościowego, nie są stopniowalne, nie funkcjonują $\mathrm{w}$ semantycznej przestrzeni zawartej między biegunami minimum i maksimum. Jak odnotowuje literatura, przejście podobnych wyrażeń do kategorii stopniowalnej zdarza się na mocy przenośni kategorialnej (por. T. Skubalanka 2002). W omawianym przypadku powtórzenie kategorii występuje w formie zleksykalizowanej. Można by w tym kontekście 
Przez użycie członu kompozycyjnego (tag- i wort-) zachodzi tu reduplikacja jako ponowna gradacja (niestopniowalnej) cechy, wyrażonej już derywacją täglich i wörtlich $^{26}$.

Jak potwierdzają przytoczone wyżej przykłady (7), liczne przypadki reduplikacji słowotwórczej są rezultatem dążenia do jednoznaczności. Tworzenie i używanie wielu leksemów bywa podyktowane obserwowanym w pewnych specyficznych domenach dyskursów zapotrzebowaniem na precyzyjność przy określaniu właściwości takich jak np. barwa, jej intensywność, odcienie lub jasność.

(11) halbrötlich [Farben: 1447] (jasno, lekko, delikatnie różowy);

hellbräunlich [P: 228] (jasno, lekko, delikatnie brązowawy);

hellrötlich [P: 173] (jasno, lekko, delikatnie różowy);

hellweißlich [biolog], (jasno, lekko, delikatnie biały) ${ }^{27}$.

Pojawienie się w konstrukcji słowotwórczej (11) członów halb- i hell-, stopniujących jasność barwy okazuje się użytkownikowi języka niewystarczające - dodatkowa gradacja jasności koloru odbywa się tu za pomocą sufiksu -lich ${ }^{28}$.

Nie są to odosobnione przykłady na występowanie pleonazmów w dyskursach specjalistycznych. Te ostatnie okazują się być domeną różnorakich powtórzeń. Komunikacyjna wartość reduplikacji oraz akceptowalność, z jaką się ona tutaj spotyka, okazują się być niezależnymi od formy i od charakteru relacji zespoleń, czy to tautologicznej (4b), (4c), czy to pleonastycznej (11), (12).

Doprecyzowanie, ujednoznacznienie wypowiedzi, dbanie o jej wyrazistość, jednocześnie zaakcentowanie i wzmocnienie wymowy uzasadniają popularność, jaką reduplikacja cieszy się w kontekstach specjalistycznych:

(12) Rückantwort ${ }^{29}$ [DR], [DUW] (odpowiedź zwrotna);

Tätigkeitshandlung [Strafrechtswissenschaft: 245] (konkretny czyn (karalny) np. w prawniczym opisie przebiegu zdarzeń kryminalnych);

poddać dyskusji inne przypadki stopniowania cechy, semu „differentiae specificae”, wpisanego w znaczenie leksemu jako najwyższy stopień właściwości rzeczy (por. ibid.). Wydobycie pewnej cechy odbywa się tu zazwyczaj ze względów pragmatycznych.

${ }^{26}$ Stopniowanie przymiotnika bądź przysłówka, jest realizowane zwykle w ramach kategorii fleksyjnych (syntetycznych), słowotwórczych lub też w formie opisowej (analitycznej). W omawianych tu przypadkach ponowne wyrażenie tożsamej cechy ma miejsce za pomocą środków słowotwórczych.

${ }^{27}$ Wyrażenie cech odbywa się w tych przypadkach w dwójnasób, w formie pleonastycznej kontaminacji wyrażeń np.: hellweiß i weißlich $\rightarrow$ hellweißlich. Przykład ten odnotował W. Fleischer $\mathrm{w}$ jednej $\mathrm{z}$ podstawowych prac $\mathrm{z}$ zakresu słowotwórstwa języka niemieckiego „Wortbildung der deutschen Gegenwartssprache“ (1982). Autor nie rozpatruje jednak tych przypadków w kontekście reduplikacji (i np. pleonazmu). Przykłady pleonastycznych nazw zapachów w języku niemieckim omawia P. Staniewski 2010: 203-215.

28 Analityczne formy konkurencyjne dla formy stopniowania oraz stylistyczne funkcje przyrostka -lich opisuje W. Fleischer 1982: 272.

${ }^{29}$ Słowniki języka niemieckiego objaśniają ten termin w następujący sposób: Antwort auf eine telefonische oder schriftliche Anfrage [DR:730 i nast.], tzn. odpowiedź na zapytanie w formie pisemnej. 
Zeittakt [Brockhaus multimedial] (takt czasowy, (impuls w telekomunikacji)) (Por. P. Bąk 2015) $)^{30}$.

\section{Kompozycja}

Szczególnie interesującą - moim zdaniem - z uwagi na specyfikę słowotwórstwa języka niemieckiego jest reduplikacja zachodząca w obrębie kompozycji determinatywnej $^{31}$. Złożenia $\mathrm{w}$ języku niemieckim są w przeważającej mierze konstruowane z zachowaniem stosunku podrzędności komponentów, w którym drugi człon struktury kompozycyjnej jest określany bliżej przez poprzedzający go komponent determinujący (por. E. Donalies 2002: 57) ${ }^{32}$.

W języku niemieckim spotkać można wiele złożeń pleonastycznych, które uwypuklają cechy pojęć. Co istotne, wydobywają one cechy istotne, nieperyferyjne. Wyrażenia takie (por. (13), (14)) są napiętnowane przez publicystów jako błędy językowe bądź niedoskonałość stylu (W. Sanders 1996, W. Schneider 1998, B. Sick 2007), jedocześnie jednak funkcjonują w polilektach, w rzeczywistości językowej i jako ,pełnoprawne" wyrażenia odnotowane są przez leksykografię (por. [DUW]) $)^{33}$ :

(13) Pulsschlag [NS], [DRecht] (uderzenia tętna);

Fußpedal [BS1], [BS2], [NS], [Pons] (pedał nożny);

Ausgangsvoraussetzung [BS2] (założenia wstępne) (Poniższe przykłady - por. też P. Bąk 2015);

Einzelindividuum [BS2], [DR] (pojedynczy człowiek/osoba);

Gesichtsmimik [DR] (mimika twarzy);

Sanddünen [BS1], [manager] (piaszczyste wydmy);

Tierfauna [Gutenberg] (fauna zwierzęca);

${ }^{30}$ Podobną relację spotykamy w przypadku użycia przydawek w naukowych określeniach: semantische Bedeutung (Bed.: 285) [znaczenie semantyczne], dreidimensionaler Raum [Heck] [przestrzeń trójwymiarowa, przestrzeń euklidesowa].

${ }^{31} \mathrm{~W}$ przeciwieństwie do derywatu niemieckie wyrazy złożone, o których tu mowa, składają się z samodzielnych członów leksykalnych. Odróżnienie derywacji od kompozycji oparte na rozróżnieniu między morfemami związanymi (w derywacji) i swobodnymi (w kompozycji) omawia szerzej W. Fleischer (1982: 49). Por. też przypis 34.

${ }^{32} \mathrm{~W}$ przypadku konstrukcji rzeczownikowych $\mathrm{w}$ języku niemieckim o rodzaju gramatycznym całego wyrazu decyduje drugi człon. Relacja determinacji w złożeniach tego typu może funkcjonować np. na zasadzie porównania (choć nie tylko w taki sposób). Jej logikę stanowi swoiste „tertium comparationis“: schneeweiß - weiß wie Schnee [DUW]; eiskalt - kalt wie Eis, sehr kalt [DUW]; samtweich - weich wie Samt [DUW]; seidenweich - weich wie Seide, sehr weich [DUW]; kreisrund - rund wie ein Kreis [DUW]; kugelrund - rund wie eine Kugel [DUW]; steinhart - hart wie ein Stein [DUW]; federleicht - leicht wie eine Feder [DUW]; wuzerldick - dick wie ein Wuzerl [DUW]. Odwrócenie relacji porównania prowadzić może do powstania wyrażeń o znamionach omawianej tu reduplikacji.

${ }^{33}$ Przykłady wpisujące się w ten kontekst W. Fleischer określa mianem złożeń ,ujednoznaczniających” („,verdeutlichende Zusammensetzungen”) (W. Fleischer 1982: 101). Uznając je niestety za zjawisko rzadkie, przytacza jedynie trzy leksemy: Schalksnarr, Haderlump (W. Fleischer 1982: 101) i Trödelkram (W. Fleischer/ I. Barz 1995: 127). Przypadki te autor objaśnia, posługując się - nomen est omen - pleonazmem: „ekspresywne wzmocnienie” (,expressive Verstärkung”) (W. Fleischer 1982: 249). 
Vorderfront [BS1], [Spiegel online 25.2.2016] (przedni front);

Zukunftsperspektive [Spiegel 6/1971] (perspektywy dotyczące przyszłości);

Zukunftsprognosen [BS1], [BS2], [Spiegel 23/1976] (prognozy dotyczące przyszłości);

Zukunftspläne [Spiegel online 16.07.2017] (plany na przyszłość).

Z uwagi na pozorny wkład semantyczny członu określającego w konstytuowanie się znaczenia całego leksemu (człon ten determinuje komponent po nim następujący jedynie formalnie, nie doprecyzowując jednak znaczenia całego leksemu), relację zachodzącą $\mathrm{w}$ tego rodzaju konstrukcjach określam mianem pseudodeterminacji ${ }^{34}$. Pleonazmy, w przypadku których ma miejsce pozorna determinacja, cechuje znaczna frekwencja w badanych dyskursach.

Wśród stwierdzonych wśród niemieckojęzycznych pleonazmów wyróżnić można następujące, szczególne przypadki reduplikacji:

Powtórzenie znaczenia wyrazu/ członu obcego przez użycie wyrażenia rodzimego ${ }^{35}$

(14) Glasvitrine [BS2] (szklana witryna);

Vogelvoliere [BS2] (woliera dla ptaków);

Düsenjet [BS2] (potocznie o odrzutowcu, synonimy: Düsenflugzeug lub Jet);

Einkaufs-Shop [BS1], [stadtarchiv] (sklep, w którym można robić zakupy).

Powtórzenie znaczenia skrótowca przez dodanie wyrażenia pełnego (nie skróconego) ${ }^{36}$

(15) ABS-System [eB] (system ABS);

$C D$-Disc [eB] (płyta CD);

GPS-System [eB] (system ABS);

$H I V$-Virus [eB] (wirus HIV);

ISBN-Nummer [eB] (numer ISBN);

$P D F$-Format $[\mathrm{eB}]$ (format PDF);

persönliche PIN-Nummer [eB] (numer PIN).

Zaznaczyć należy, że przykładów na kontrowersyjne słowotwórstwo nie brakuje głównie w prowadzonych przez laików dyskursach pseudospecjalistycznych, w tym na forach internetowych:

(16) beschreibbare $C D-R$ [HiFi] (dający się zapisać CDR);

Leucht-LED [techniker-forum] (świecąca dioda LED);

\footnotetext{
${ }^{34} \mathrm{Na}$ fakt ten zwróciłem uwagę w artykule „Pleonasmus der deutschen Gegenwartssprache” (P. Bąk 2015). Pleonazmy te zbudowane są w oparciu o mechanizm kompozycji determinatywnej. Omawiane tu przypadki nie mogą być rozpatrywane jako złożenia adytywne („Kopulativkomposita”). Te funkcjonują na zasadzie współrzędności i sumaryczności członów, które nie determinują się wzajemnie formalnie i semantycznie (np. Dichterkomponist, Strumpfhose itp.). Przeciw potraktowaniu przykładów (13), (14) jako tautologie przemawia fakt widocznej w nich formalnej, strukturalnej determinacji, którą z uwagi na ich semantykę określić należy - powtórzę - pseudodeterminacją.

${ }^{35}$ Pod tym względem użycie wyrazów obcego pochodzenia jest źródłem redundancji również w przypadku omówionej szerzej w P. Bąk (2015) derywacji oraz w użyciu przydawki.

${ }^{36}$ Powyższe przykłady omówiłem z przywołaniem językowego kontekstu, w jakim występują w dyskursie, w innej pracy (por. P. Bąk 2015: 15).
} 
HDD-Festplatte [pc-forum], [Brockhaus multimedial] (twardy dysk HDD).

Wyrażaną w krytycznej wobec pleonazmów leksykografii (por. [DR]) negatywną ocenę wyrażeń tłumaczy nie fakt, że pleonazm wydobywa centralne cechy pojęć, lecz odmienność form językowych, przy pomocy których cechy te są wyrażane. Jednak i wśród takich niemieckich pleonazmów kompozycyjnych znajdziemy mnóstwo reduplikacji powszechnie akceptowanych, używanych i odnotowywanych w słownikach języka niemieckiego np. w [DUW]. Oto wybrane spośród najbardziej powszechnych sformułowań, które przedstawiam też w pracy P. Bąk 2011c:

(17) Kriegsveteran [DUW] (weteran wojenny);

Volksdemokratie [BS1], [DRecht] (demokracja ludowa);

Zeitdauer [DUW] (czas trwania);

scharfkantig [DUW] (o ostrych kantach);

Schulungskurs [DUW] (kurs szkoleniowy);

Trommelrevolver [DUW] (rewolwer bębenkowy);

Zeitverzögerung [Brockhaus multimedial] (opóźnienie w czasie);

Haifisch [DUW] (rekin, dosłownie: ryba-rekin).

Fakt, że reduplikacja wydobywa tu centralne cechy pojęć, wydawać mogłoby się być przyczyną braku akceptowalności dla pleonazmu. Okazuje się - i jest to pewna symptomatyczna cecha reduplikacji (akceptowanej przez użytkowników języka), że pleonazmy bardzo często wydobywają cechy prototypowe.

\section{Uwagi końcowe}

Zasadniczym spostrzeżeniem poczynionym $\mathrm{w}$ analizie pleonazmów niemieckich jest realność czy wręcz wszechobecność reduplikacji w autentycznych dyskursach ${ }^{37}$. Spojrzenie na zjawisko wymaga neutralnego podejścia do problematyki, tzn. takiego, które unika uogólnień, uwzględnia indywidualne oceny wydawanych przez poszczególnych użytkowników języka, w których świadomości - jak powiada A. MałochaKrupa (2003: 132) - dokonuje się kategoryzacja na zasadach innych niż wyłącznie czysto zdroworozsądkowe, taksonomiczne, naukowe czy też słownikowe.

Opierając się na założeniach lingwistyki antropocentrycznej przyjąć należy, że u konkretnych ludzi, w ramach ich idiolektów (por. S. Grucza 2013: 87, 94 i nast.) możliwe jest i w rzeczywistości ma miejsce wydobywanie przez pleonazm pewnych kategorii pojęć. Co znamienne, zaakceptowane przez leksykografię niemieckie pleonazmy kompozycyjne naświetlają centralne, nieperyferyjne cechy. Potraktowanie ich jako właściwości związane $\mathrm{z}$ wiedzą zinternalizowaną przez poszczególnych użytkowników języka, umożliwić może dostrzeżenie pozytywnego wymiaru pleonazmu.

Reduplikacje pojawiają się często jako zamierzone powtórzenie treści. Z punktu widzenia nadawcy jest to zatem akceptowalna nadwyżka semantyczna, za którą kryje się konkretna intencja i pewna wartość komunikacyjna.

${ }^{37}$ Realny udział reduplikacji semantycznych w funkcjonowaniu i rozwoju języka omówiłem w innym kontekście (P. Bąk 2015) na przykładzie niemieckojęzycznych tautologicznych form bliźniaczych. 
Jak słusznie twierdzi A. Małocha-Krupa (2003) i co potwierdzają zebrane przykłady niemieckojęzyczne, rozważań na temat reduplikacji nie można ograniczać do postrzegania jej przez pryzmat redundancji czy też błędu. Należy ją rozpatrywać m.in. w kategoriach różnic między idiolektami, między aktualizowanym znaczeniem nadawanym wyrażeniom przez autora a statusem rekonstruowanym przez odbiorcę.

Generalizujące, negatywne oceny dla pleonazmów usprawiedliwiać można faktem, że ten środek wyrazu (podobnie zresztą jak i tautologia) często ma charakter transkategorialny, tzn. jest reduplikacją semantyczną realizowaną za pomocą członów różniących się od siebie pod względem morfosyntaktycznym, są to bowiem różne części mowy lub inne części zdania.

Nie wszystkie pleonazmy mają szansę zaistnieć i przetrwać w polilektach. Powołując się na F. Gruczę (2017c: 151 i nast.), pragnę zwrócić uwagę na wartość innowacji językowych, które mają charakter naturalny. Mogą zostać zaakceptowane przez wspólnotę użytkowników języka, choć mogą też spotkać się z dezaprobatą. W ten właśnie sposób dokonuje się niewymuszony, naturalny rozwój języka:

Otóż lingwistyka [...] musi koniecznie odróżnić przede wszystkim dwa rodzaje upowszechniania (się) w obrębie danej wspólnoty poszczególnych zmian lub innowacji - naturalne i wymuszone. $\mathrm{Z}$ pierwszym rodzajem, który nazwać można też dobrowolnym lub spontanicznym, mamy do czynienia wtedy, gdy zainicjowana zmiana lub zaproponowana innowacja jest przez innych akceptowana (głównie) ze względu na nią samą, tzn. na przykład z uwagi na jej jakąś funkcjonalną wartość. Natomiast o drugim możemy mówić wówczas, gdy ktoś, kto ich nie akceptuje, musi się liczyć z nieprzyjemnościami lub nawet z różnego rodzaju sankcjami czy zgoła represjami. (F. Grucza 2017c: 151)

Roztrząsanie kwestii akceptowalności reduplikacji z pewnością nie może sprowadzać się do pytania o jej formę, strukturę, ani nawet o charakter relacji między członami reduplikacji (o determinację czy też współrzędność), zatem nie powinno ograniczać się do taksonomicznego ujęcia i identyfikacji reduplikacji jako pleonazm czy też tautologia. W tym sensie traktuję powyższe rozważania jako wymagające dalszej pogłębionej refleksji (por. przypis 3).

\section{Bibliografia}

Antoniak, D. (2005), Reduplikacje jako uniwersalium jezykowe, (w:) „Investigationes Linguisticae", vol. XII, Poznań. (URL http://www.staff.amu.edu.pl/ inveling/pdf/antoniak_inve12.pdf). [Pobrano 4.4.2017].

Bąk, P. (2011a), Grammatisch überflüssig oder lexikalisch komplementär? Vorüberlegungen zur kontrastiven Betrachtung von Tautologie und Pleonasmus im Deutschen und Polnischen, (w:) M. Wierzbicka/ Z. Wawrzyniak (red.), Grammatik im Text und Diskurs (=Danziger Beiträge zur Germanistik 34). Frankfurt a. M., 261-276.

Bąk, P. (2011b), Ist „tautologisch“ fehlerhaft, akzeptabel oder rhetorisch relevant?, (w:) I. Bartoszewicz/ J. Szczęk/ A. Tworek (red.), Germanistische Linguistik im interdisziplinären Gefüge II (=Linguistische Treffen in Wrocław 7). Dresden/ Wrocław, 23-32. 
Bąk, P. (2011c), Sind Wiederholungen immer redundant? Zu Formen und Funktionen von Pleonasmen im Bereich der Wortbildung, (w:) D. Kaczmarek/ J. Makowski/ M. Michoń/ Z. Weigt (red.), Felder der Sprache - Felder der Forschung (Lodzer Germanistikbeiträge 1). Łódź, 33-42.

Bąk, P. (2015), Pleonasmus der deutschen Gegenwartssprache, (w:) I. Bartoszewicz/ J. Szczęk / A. Tworek (red.), Linguistische Treffen in Wrocław. Tom 11. (Phrasenstrukturen und -interpretationen in Gebrauch II). Dresden/ Wrocław, 11-23.

Bußmann, H. (2002), Lexikon der Sprachwissenschaft. Stuttgart.

Buttler, D. (1971), Źródła „redundancji” leksykalnej, (w:) „Prace Filologiczne“, t. 11, 249-263.

Czochralski, J. (1990), Gramatyka niemiecka dla Polaków. Warszawa.

Dauses, A. (2000), Ökonomie und Kybernetik natürlicher Sprachen. Stuttgart.

Donalies, E. (2002), Die Wortbildung des Deutschen. Ein Überblick. Tübingen.

Fleischer, W. (1982), Wortbildung der deutschen Gegenwartssprache. Tübingen.

Fleischer, W./ I. Barz, (1995), Wortbildung der deutschen Gegenwartssprache. Tübingen.

Grice, H. P. (1975), Logic and Conversation, (w:) P. Cole/ J.L. Morgan (red.), Syntax and Semantics 3: Speech Acts. New York, 41-58.

Grucza, F. (2017a), Język, ludzkie właściwości językowe, językowa zdolność ludzi, (w:) S. Grucza/ M. Olpińska-Szkiełko/ M. Płużyczka et al. (red.), Franciszek Grucza. Dzieła zebrane. Tom 3. O języku, językach i lingwistyce. Wydanie jubileuszowe z okazji 80. rocznicy urodzin. Warszawa, 43-69.

Grucza, F. (2017b), O wieloznaczności nazwy ,język”, heterogeniczności zwiąanych z nim desygnatów i istocie rzeczywistych języków ludzkich, (w:) S. Grucza/ M. Olpińska-Szkiełko/ M. Płużyczka et al. (red.), Franciszek Grucza. Dzieła zebrane. Tom 3. O języku, językach i lingwistyce. Wydanie jubileuszowe z okazji 80. rocznicy urodzin. Warszawa, 97-126.

Grucza, F. (2017c), Problemy historii i genezy języków ludzkich, (w:) S. Grucza/ M. Olpińska-Szkiełko/ M. Płużyczka et al. (red.), Franciszek Grucza. Dzieła zebrane. Tom 3. O języku, językach i lingwistyce. Wydanie jubileuszowe z okazji 80. rocznicy urodzin. Warszawa, 141-161.

Grucza, S. (2013), Lingwistyka języków specjalistycznych. Warszawa.

Hoffmann, L. (1998), Syntaktische und morphologische Eigenschaften von Fachsprachen, (w:) L. Hoffmann/ H. Kalverkämper et al. (red.), Fachsprachen. Ein internationales Handbuch zur Fachsprachenforschung und Terminologiewissenschaft. (Handbücher zur Sprach- und Kommunikationswissenschaft 14.1). Berlin/ New York, 416-427.

Hoffmann, M. (2008), Mikro- und makrostilistische Einheiten im Überblick/ Microand macrostylistic elements: An overview, (w:) U. Fix/ A. Gardt/ J. Knape (red.), Rhetorik und Stilistik. Ein internationales Handbuch historischer und systematischer Forschung. Halbband 2. (Handbücher zur Sprach- und Kommunikationswissenschaft 31.2). Berlin/ New York, 1529-1545.

Humboldt, W. von (1836/1963), Über die Verschiedenheit des menschlichen Sprachbaus und ihren Einfluß auf die geistige Entwicklung des Menschengeschlechts, 
(w:) A. Flitner/ K. Giel (red.), (1836/1963) Humboldt-Studienausgabe. Darmstadt, 144-367.

Małocha-Krupa, A. (2003), Stowa w lustrze. Pleonazm - semantyka-pragmatyka. Wrocław.

Martinet, A. (1981), Sprachökonomie und Lautwandel. Eine Abhandlung über die diachronische Phonologie. Stuttgart.

Polański, K. (red.) (2003), Encyklopedia Językoznawstwa Ogólnego. Wrocław/ Warszawa/ Kraków.

Roelcke, T. (2002), Synthetischer und analytischer Sprachbau in den deutschen Fachsprachen der Gegenwart, (w:) Das Wort. Germanistisches Jahrbuch der GUS 2002. Moskau. 179-195.

Roelcke, T. (2004), Analytismus im Deutschen, (w:) U. Hinrichs (red.), Die europäischen Sprachen auf dem Wege zum analytischen Sprachtyp (unter Mitarbeit von Uwe Büttner) (Eurolinguistische Arbeiten 1). Wiesbaden, 147-168.

Sanders, W. (1996), Gutes Deutsch - besseres Deutsch. Praktische Stillehre der deutschen Gegenwartssprache. Darmstadt.

Schneider, W. (1998), Deutsch für Kenner. Die neue Stilkunde. Zürich.

Sick, B. (2007), Zweifach doppelt gemoppelt, (w:) B. Sick (red.), Der Dativ ist dem Genitiv sein Tod 3. Köln, 29-34. [BS1]

Sick, B. (2005), 48 Beispiele für Pleonasmen, (URL http://bastiansick.de/kolumnen/zwiebelfisch/48-beispiele-fuer-pleonasmen/). [Pobrano 4.4.2017]. [BS2].

Skubalanka, T. (2002), Podstawy analizy stylistycznej. Rozważania o metodzie. Lublin.

Sperber, D./ Wilson, D. (1986), Relevance: Communication and cognition. Oxford.

Staniewski, P. (2010), Inwieweit sind die Geruchsbezeichnungen als Pleonasmen einzustufen?, (w:) „Germanica Wratislaviensia“, Tom 130, 203-215.

\section{Słowniki}

Brockhaus multimedial (2003), Mannheim [Brockhaus multimedial].

Duden (2003), Duden - Deutsches Universalwörterbuch. Mannheim/ Leipzig/ Wien/ Zürich [DUW].

Duden (2001), Duden - Richtiges und gutes Deutsch. Mannheim/ Leipzig/ Wien/ Zürich [DR].

Duden (2001), Duden - Die deutsche Rechtschreibung. Mannheim/ Leipzig/ Wien/ Zürich [DRecht].

Pons Onlinewörterbuch (URL http://de.pons.com) [Pobrano 4.4.2017] [Pons].

Tokarski, J. (red.) (1980), Słownik wyrazów obcych PWN. Warszawa [Słownik wyrazów obcych PWN].

\section{Źródla}

Der Spiegel [Spiegel 6/1971], [Spiegel 23/1976], [Spiegel 11/2000].

Dronsch, K. (2010), Bedeutung als Grundbegriff neutestamentlicher Wissenschaft: texttheoretische und semiotische Entwürfe zur Kritik der Semantik dargelegt anhand einer Analyse zu akouein in Mk 4. Tübingen-Basel. [Bed.: 285]. 
Heck, T. (1993), Methoden und Anwendungen der Riemannschen Differentialgeometrie in Yang-Mills-Theorien. Stuttgart. [Heck].

Jones, W.J. (2013), Historisches Lexikon deutscher Farbbezeichnungen. Berlin. [Farben: 1447].

Lindau, G./ Ulbrich, E. (1928/2013), Die höheren Pilze: Basidiomycetes. Berlin. [P: 173], [P: 228].

Rost, W. (2013). Emotionen: Elixiere des Lebens. Berlin. [psycholog: 475].

Zeitschrift für die gesamte Strafrechtswissenschaft, 94. [Strafrechtswissenschaft: 245].

\section{Źródla internetowe}

URL http://gutenberg.spiegel.de/?id=12\&xid=41\&kapitel=9\&cHash=d614f1 e 822 chap09 [Pobrano 4.12.2010] [Gutenberg].

URL http://www.handelsblatt.com/archiv/tipps-fuer-wissenschaftliche-arbeitenschoener -schreiben/2181998.html [Pobrano 10.8.2017] [hb].

URL http://www.hifi-forum.de/viewthread-26-17066.html[Pobrano4.12.2010] [HiFi].

URL http://www.manager-magazin.de/lifestyle/reise/golfreisen-die-besten-zielefuer-herbst-und-winter-a-1169082.html [Pobrano 4.12.2010] [manager].

URL https://www.markt.de/nordrhein-westfalen/dienstleistungen/k/f\%C3\%A4rber+heilkr\%C3\%A4uter+weiterbildung/ [Pobrano 4.12.2010] [biolog].

URL http://www.nasenforum.de/vbulletin/showthread.php?t=10561\&page=2 [Pobrano 4.12.2010] [forum]

URL https://neueswort.de/pleonasmus/ [Pobrano 4.12.2010] [NS].

URL http://www.pc-magazin.de/ratgeber/ssd-oder-hdd-hybrid-vorteile-nachteilefestplatten-ratgeber-1472408.html [Pobrano 4.12.2010] [pc-forum].

URL http://www.spiegel.de/panorama/justiz/natascha-kampusch-neue-anzeige-wegen-mordes-zum-tod-von-priklopil-a-1079214.html [Pobrano 10.8.2017] [Spiegel online 25.2.2016].

URL http://www.spiegel.de/politik/deutschland/angela-merkel-zu-g20-krawallenwir-haben-das-gemeinsam-gestaltet-a-1158151.html [Pobrano 10.8.2017] [Spiegel online 16.07.2017].

URL http://www.stadtarchiv-bad-bevensen.de/d0101h-handel-handwerk-gewerbe/d0101h-0131 [Pobrano 4.12.2010] [stadtarchiv].

URL http://www.taz.de/Archiv-Suche/!5160263\&s=/ [Pobrano 10.8.2017] [taz7.7.09].

URL https://www.techniker-forum.de/thema/suche-aluminium-profile-fuerleucht-led.107999/ [Pobrano 4.12.2010] [techniker-forum].

URL https://www.welt.de/print/die_welt/kultur/article11383173/Ich-will-immerwieder-neu-anfangen-das-geht.html [Pobrano 4.12.2010] [welt].

URL https://www.world-architects.com/fa/projects/view/jugendwohnheim [Pobrano 4.12.2010] [architekt].

materiały inne: instrukcje [eB]. 